https://doi.org/10.18778/0208-6069.97.08

Michalina Barylska*

\title{
MOŻLIWOŚĆ WYKORZYSTANIA KLAUZULI \\ REBUS SIC STANTIBUS DLA OCHRONY STRON STOSUNKÓW ZOBOWIĄZANIOWYCH DOTKNIĘTYCH SKUTKAMI PANDEMII WIRUSA SARS-COV-2
}

\begin{abstract}
Streszczenie. Artykuł podejmuje problem stosowania klauzuli rebus sic stantibus, wyrażonej w art. 357(1) k.c., w związku z wprowadzeniem przez Ministra Zdrowia na terytorium Rzeczypospolitej Polskiej stanu zagrożenia epidemicznego, a następnie stanu epidemii wirusa SARS-CoV-2. Celem niniejszego artykułu jest ustalenie, czy dopuszczalne jest zastosowanie klauzuli w celu łagodzenia skutków pandemii, które dotykają strony stosunków zobowiązaniowych oraz w stosunku do jakich umów klauzula znajdzie zastosowanie. Autorzy analizują, w jakich okolicznościach możliwe jest zwrócenie się do sądu z żądaniem oznaczenia sposobu wykonania zobowiązania, zmiany wysokości świadczenia czy orzeczenia o rozwiązaniu umowy. Zwrócono także uwagę na konieczność ścisłej wykładni normy z art. 357(1) k.c. W artykule zaprezentowano pogląd, że na efektywność klauzuli rebus sic stantibus może wpłynąć dopuszczenie możliwości formułowania zarzutu na podstawie art. 357(1) k.c.
\end{abstract}

Słowa kluczowe: stan epidemii, zmiana sposobu wykonania zobowiązania, rozwiązanie umowy, sądowa modyfikacja stosunku prawnego, klauzula rebus sic stantibus.

\section{POSSIBILITY OF USING REBUS SIC STANTIBUS CLAUSE FOR THE PROTECTION OF PARTIES OF CONTRACTUAL RELATIONS AFFECTED BY THE EFFECTS OF SARS-COV-2}

\begin{abstract}
This article deals with the problem of application of rebus sic stantibus clause, set forth in Art. 357(1) of the Civil Code, in conjunction with announcing by the Minister of Health a state of epidemiological emergency in the territory of the Republic of Poland, and, subsequently, the state of SARS-CoV-2 epidemic. This article aims to determine whether it is permissible to apply the foregoing clause in order to mitigate the effects of the pandemic that may affect a party to contractual relationships and also in relation to which contracts the foregoing clause shall be applicable. The authors analyse, under what circumstances it shall be possible to apply to a court
\end{abstract}

\footnotetext{
*Uniwersytet Łódzki, Wydział Prawa i Administracji, barylskamich@gmail.com

** Uniwersytet Łódzki, Wydział Prawa i Administracji, UL0221781@edu.uni.lodz.pl
} 
of law with a motion to determine a manner of performing anobligation, with a motion to change the amount of performance or with a motion to terminate a contract. Attention was drawn to the necessity to have a narrow interpretation of the norm set forth in Art. 357(1) of the Civil Code. An opinion has been presented in this article that the effectiveness of rebus sic stantibus clause may be affected by an admissibility to formulate a claim in pursuance of Art. 357(1) of the Civil Code.

Keywords: state of epidemic, change to the manner of performance of an obligation, contract termination, judicial modification of a legal relationship, rebus sic stantibus clause.

\section{WSTĘP}

Niespodziewany wybuch pandemii SARS-CoV-2 i związane z tym regulacje prawne, jakie wprowadza państwo w celu przeciwdziałania rozprzestrzenianiu się koronawirusa, niosą poważne konsekwencje dla uczestników obrotu prawnego i choć owe skutki odczuwalne będą w różnym stopniu, stronom stosunków zobowiązaniowych zależeć będzie na znalezieniu rozwiązania, mającego zapewnić im skuteczną ochronę. Jedną z instytucji, wskazywaną jako potencjalnie możliwą do wykorzystania, jest tzw. klauzula rebus sic stantibus z art. 357(1) ustawy z 23.04.1964 r. - Kodeks cywilny (Dz.U.2020.1740 t.j. z dnia 8.10.2020 r.). Możliwość zastosowania tej klauzuli w odniesieniu do pandemii koronawirusa nie może być jednak uznana za oczywistą, ponieważ w związku z wymienionymi przez ustawodawcę przesłankami stosowania art. 357(1) k.c., tj. wystąpieniem nadzwyczajnej zmiany stosunków, nadmiernych trudności albo groźby rażącej straty dla jednej ze stron przy spełnianiu świadczenia oraz nieprzewidzeniem tego przez strony przy zawieraniu umowy, należy zbadać, czy pandemia COVID-19 prowadzi w ogóle do owej nadzwyczajnej zmiany stosunków, a jeśli tak, to w jakim zakresie i w jaki sposób możliwe będzie skorzystanie ze wskazanego przepisu.

\section{NADZWYCZAJNA ZMIANA STOSUNKÓW W ROZUMIENIU ART. 357(1) K.C. A PANDEMIA SARS-COV-2}

Pierwszą z przesłanek stosowania art. 357(1) k.c. jest zaistnienie nadzwyczajnej zmiany stosunków. Przyjmuje się, że chodzi tutaj o zmianę społeczno-gospodarczą, która nie mieści się w granicach zwykłego ryzyka kontraktowego oraz mającą ogólny, powszechny charakter, dotyczącą wielu podmiotów oraz niezależną od woli stron (tak m.in. wyr. SN z dn. 19.11.2014 r., II CSK 191/14, Lex Nr 1628911). Część doktryny podkreśla w tym miejscu, iż przyczyna wywołująca owe niebywałe skutki, choć nie musi być nadzwyczajna, powinna mieć charakter katastroficzny (Kurosz, Matysiak 2020). Stanowi to nawiązanie do dawnego kształtu klauzuli rebus sic stantibus. Zgodnie z Rozporządzeniem Prezydenta Rzeczypospolitej Polskiej z 27.10.1933 r. - Kodeks zobowiązań 
(Dz.U. Nr 82, poz. 59) nadzwyczajnymi zdarzeniami uzasadniającymi zastosowanie tej konstrukcji są m.in. wojna, zaraza, nieurodzaj. Można jednak spotkać się także ze stanowiskiem, iż poprzez takie zapatrywanie ogranicza się zastosowanie klauzuli rebus sic stantibus do przypadków, które niezmiernie rzadko występują w praktyce. Konsekwencją jest więc zbyt rygorystyczne oznaczenie granic stosowania klauzuli i w efekcie istotne zredukowanie znaczenia omawianej instytucji (Brzozowski 2020, 49). Stanowisko takie jednak nie przekonuje, w kontekście postrzegania art. 357(1) k.c. jako wyjątku od zasady pacta sunt servanda (Robaczyński 1998, 6), w związku z czym zastosowanie wykładni rozszerzającej i korzystanie z przepisu wydaje się nieuzasadnione w sytuacji, gdy nadzwyczajna zmiana zaistniała jedynie w ramach konkretnego, indywidualnego stosunku zobowiązaniowego i tym samym nie jest zjawiskiem powszechnym, nie ma znaczenia dla żadnego innego zobowiązania. Jako przykład można podać w tym miejscu zawarcie umowy najmu na czas oznaczony, a następnie domaganie się przez najemcę wcześniejszego jej rozwiązania z uwagi na to, iż w związku z niespodziewanym bankructwem pracodawcy i utratą pracy dalsze spełnianie świadczenia w postaci zapłaty czynszu łączy się dla niego z nadmiernymi trudnościami o charakterze majątkowym. Choć zdarzenie to pozostaje niezależne od woli stron i rzeczywiście dłużnik może mieć problem z wykonaniem zobowiązania, to jednak brak tutaj powszechnego charakteru - utrata pracy w tej sytuacji nie wynika z okoliczności, które mają znaczenie dla szerszego grona uczestników obrotu prawnego. Rodzi to bowiem kłopot tylko dla tego konkretnego stosunku zobowiązaniowego, w związku z czym stosowanie art. 357(1) k.c. w takich przypadkach mogłoby prowadzić do destabilizacji obrotu prawnego, a sama klauzula nie miałaby już w praktyce wyjątkowego znaczenia. Pamiętać również trzeba, że nadzwyczajność musi cechować zmianę stosunków, nie zaś zdarzenie, które ją powoduje. Może się bowiem zdarzyć, że przyczyny „zwyczajne" doprowadzą do nadzwyczajnych skutków (Morek 2020, 19). Zwracać więc należy uwagę nie tyle na fakt wystąpienia pandemii (choć niewątpliwie jest to zjawisko wyjątkowe i niespodziewane), co na skutki, jakie niesie dla uczestników obrotu, którzy z powodu ograniczeń wprowadzonych w ramach walki z pandemią muszą zmagać się z szeregiem trudności. Biorąc pod uwagę powyższe, zauważyć można, że pandemia koronawirusa niewątpliwie ma katastroficzny charakter. Mimo podejmowanych prób, nie da się zapobiec dalszym zakażeniom wirusem SARS-CoV-2, co więcej, pandemia nastąpiła niespodziewanie, a jej skali nie można było przewidzieć. Zmiany, jakie zaistniały na skutek SARS-CoV-2 oddziałują pośrednio lub bezpośrednio na wszystkich uczestników obrotu, pozostając jednocześnie niezależnymi od ich woli. Należy zwrócić uwagę również na to, że zachodzące zmiany mają nie tylko wymiar gospodarczy, np. zamknięcie określonych obiektów, jak restauracje czy hotele, skutkujące pozbawieniem ich właścicieli źródła dochodów, ale i w pewnym stopniu społeczny - w czasie pandemii wiele osób z obawy przed możliwym zakażeniem 
pozostało $\mathrm{w}$ domu, zachowywało dystans społeczny, co z kolei przełożyło się na mniejsze zainteresowanie produktami oferowanymi na rynku, co pozostało nie bez wpływu na gospodarkę. Należy mieć również na uwadze, że wiele osób z własnej woli zdecydowało się na czasowe zaprzestanie działalności w obawie o własny stan zdrowia.

\section{ZMIANA PRZEPISÓW JAKO NADZWYCZAJNA ZMIANA STOSUNKÓW}

Kwestią sporną pozostaje odpowiedź na pytanie, czy zmiana przepisów może zostać zakwalifikowana jako nadzwyczajna zmiana stosunków. Problem ten jest istotny z uwagi na fakt, że to właśnie na skutek zmian w przepisach - wprowadzania nowych regulacji w celu ograniczenia rozprzestrzeniania się epidemii - wykonanie zobowiązań grozi w wielu przypadkach rażącą stratą bądź wiąże się z nadmiernymi trudnościami. Część doktryny wyraża pogląd, iż zmiany takie jako zjawisko zewnętrzne i niezależne od woli stron mogą być uznane za nadzwyczajną zmianę stosunków (Brzozowski 2020, 52). A. Malarewicz zauważa jednak, że z uwagi na przewlekłość prac legislacyjnych i powszechny dostęp do projektów aktów prawnych, trudno jest niekiedy upatrywać nadzwyczajnych czy zaskakujących zmian, bo z obowiązku zachowania należytej staranności przy wykonywaniu zobowiązań wynika konieczność zapoznania się z planowanymi modyfikacjami (Malarewicz 2005). Spostrzeżenie to warte jest uwagi, ale nie znajdzie zastosowania w dobie pandemii, ponieważ sytuacja epidemiczna i związane z nią reakcje państwa wciąż pozostają rozwojowe i trudno przewidzieć, kiedy i jakie zmiany prawne zostaną jeszcze wprowadzone, brak jest też jednolitego stanowiska władz publicznych w odniesieniu do poszczególnych zaostrzeń wprowadzanych z uwagi na stan pandemii. W związku z tym należałoby przyjąć, że zmiany w przepisach można w tej sytuacji uznać za nadzwyczajną zmianę stosunków, mającą istotne znaczenie dla sytuacji uczestników obrotu. Należy w tym miejscu dodać, że modyfikacje te są niezależne od woli ich adresatów oraz mają powszechny charakter - dostosować musi się do nich każdy, co tylko utwierdza w wyrażonym przekonaniu. To samo stanowisko prezentuje SN, twierdząc, że zmiana stanu prawnego, jako zdarzenie zewnętrzne, niezależne od - najczęściej - rozbieżnej woli stron, kiedy jest niemożliwa do przewidzenia przez nie w chwili zawarcia umowy, co do zakresu i kształtu przyjętych zmian, jeżeli wpływa istotnie na sytuację nie tylko dłużnika, ale i wierzyciela, powinna być traktowana, jako nadzwyczajna zmiana stosunków w rozumieniu art. 357(1) k.c. (wyr. SN z 16.05.2007 r., III CSK 452/06, Lex Nr 334987). 


\section{NADMIERNE TRUDNOŚCI ZWIĄZANE ZE SPEŁNIENIEM ŚWIADCZENIA ORAZ GROŹBA RAŻĄCEJ STRATY DLA JEDNEJ ZE STRON ZOBOWIĄZANIA}

Drugą wymienioną przez ustawodawcę przesłanką zastosowania art. 357(1) k.c. jest pojawienie się nadmiernych trudności w spełnieniu świadczenia. Wiąże się to z zachwianiem równowagi kontraktowej, zakwestionowaniem ekonomicznego sensu świadczeń i zniweczeniem celów, których osiągnięcie strony zakładały, zawierając umowę (Morek 2020, 25). Należy przy tym zaznaczyć, że spełnienie świadczenia musi być w ogóle możliwe. W przeciwnym razie stosuje się przepisy dotyczące niemożliwości świadczenia (Olejniczak 2018, 134). Jako przykład posłużyć tutaj może sytuacja, w której narzeczeni zawarli (przed wprowadzeniem stanu zagrożenia epidemicznego) umowę z właścicielem restauracji, dotyczącą zorganizowania uroczystości weselnej, ale na skutek wybuchu pandemii tego typu lokale zostały zamknięte i nie było już możliwe spełnienie świadczenia w postaci zorganizowania przyjęcia. Poza tym przyjmuje się, że trudności dotyczyć mają dłużnika i mogą mieć charakter techniczny (brak określonych materiałów), osobisty (np. spełnienie świadczenia mogłoby grozić dłużnikowi niebezpieczeństwem utraty życia) lub majątkowy (np. w następstwie klęski żywiołowej spełnienie świadczenia wiązać się będzie z koniecznością poniesienia nadmiernych nakładów i kosztów w stosunku do branych pod uwagę w momencie zawierania umowy (Brzozowski 2020, 60-61). Jak zauważa przy tym R. Strugała, art. 357(1) k.c. nie można zastosować do modyfikacji czy rozwiązania umów, na podstawie których dłużnik świadczy usługi medyczne, paramedyczne bądź związane z obsługą podmiotów świadczących takie usługi (Strugała 2020). Z jednej strony jest to słuszne zapatrywanie, ponieważ świadczenia tego typu są szczególnie istotne nie tylko w dobie pandemii. Warto tutaj wskazać także podmioty spełniające równie istotne zadania, a niezwiązane bezpośrednio z ochroną zdrowia, tj. straż pożarna, służba więzienna, policja. $Z$ drugiej jednak strony, jeżeli osoba świadcząca tego typu pracę znajduje się w grupie osób najbardziej narażonych na zakażenie SARS-CoV-2, to przy spełnieniu wszystkich przesłanek art. 357(1) k.c. powinna mieć możliwość skorzystania z owej regulacji.

Alternatywą dla nadmiernej trudności jest groźba rażącej straty dla jednej ze stron zobowiązania i tak samo wiąże się z podważeniem sensu spełnienia świadczenia na skutek zmiany okoliczności. Groźba taka może wystąpić jednak nie tylko po stronie dłużnika, ale i wierzyciela. Problemem pozostaje jednak kwestia tego, jakie okoliczności trzeba wziąć pod uwagę, próbując ocenić, czy przesłanka ta zachodzi. Istnieją tu dwa poglądy. Według pierwszego z nich o rażącej stracie decyduje nie samo porównanie aktualnej wartości świadczeń, ale całokształt skutków wykonania zobowiązania dla majątku strony, przy uwzględnieniu celu zobowiązania i tego, jakich korzyści z jego wykonania strona mogła się spodziewać (wyr. SN z dn. 19.11.2014 r., II CSK 191/14, Lex Nr 1628911). 
Natomiast zgodnie z drugim stanowiskiem, powinno się porównać sytuację majątkową powoda, w jakiej znalazłby się, gdyby wykonał umowę w warunkach występującej w chwili orzekania nadzwyczajnej zmiany stosunków oraz sytuację, w jakiej byłby, gdyby nie doszło do zmian (Strugała 2020). Za przyjęciem pierwszej z przywołanych koncepcji przemawia fakt, że wydaje się ona sprawiedliwszym rozwiązaniem. Nie powinno się pomijać celu, w jakim zobowiązanie powstało, ani spodziewanych korzyści, bo stanowią one istotny element, często decydujący o powstaniu zobowiązania. Warto też podkreślić, że nie sposób jednoznacznie odpowiedzieć, jaką stratę uznajemy za rażącą, bo każdą sprawę należy ocenić indywidualnie - przykładowo rażąca strata w odczuciu prowadzącego osiedlowy sklep byłaby bez znaczenia dla właściciela sieci supermarketów.

\section{NIEMOŻLIWOŚĆ PRZEWIDZENIA PRZEZ STRONY NADZWYCZAJNEJ ZMIANY STOSUNKÓW I JEJ WPLYWU NA WYKONANIE ZOBOWIĄZANIA}

Zastosowanie klauzuli rebus sic stantibus wymaga także spełnienia przesłanki nieprzewidzenia przez strony skutków danych zdarzeń. Zgodnie z brzmieniem artykułu 357(1) k.c. strony, przy spełnieniu pozostałych ustawowych przesłanek, będą mogły skorzystać z klauzuli, jeżeli nie mogły przewidywać nadzwyczajnej zmiany stosunków z chwilą zawarcia łączącej je umowy. Jednakże, zgodzić należy się z poglądem prezentowanym w doktrynie, a także w orzecznictwie SN, zgodnie z którym wbrew literalnemu brzmieniu art. 375(1) k.c., problem przewidywalności wiąże się nie tyle z przewidywaniem przez strony zdarzeń, które powodują dla jednej z nich nadmierne trudności lub rażącą stratę, lecz z przewidywaniem następstw tych zdarzeń, wymaga się więc, by strony nie mogły przewidzieć swojej przyszłej sytuacji z chwilą zawarcia umowy (Olejniczak 2018, 129). Regulacja $\mathrm{z}$ art. 357(1) k.c. nie wyłącza więc zastosowania klauzuli w stosunku do zdarzeń, których przebieg można co prawda przewidzieć, ale niemożliwym lub bardzo trudnym do przewidzenia jest ich wpływ na dane zobowiązanie (Wiśniewski $2018,12)^{1}$. Wirus SARS-CoV-2 został co prawda po raz pierwszy rozpoznany i opisany już w grudniu 2019 r., jednakże założenie, że już ten moment był na tyle przełomowy, by od niego, jako od punktu wyjścia, można było przewidywać, że będzie miała miejsce globalna pandemia, jest nietrafne.

Podejmując rozważania w kontekście ustalenia momentu, od którego strony mogły przewidzieć, jakie następstwa wywoła pandemia koronawirusa, odnotować należy chronologię zdarzeń następujących w związku z pojawieniem się pandemii w Polsce. 27 lutego 2020 r. zostało wydane rozporządzenie Ministra Zdrowia w sprawie zakażenia koronawirusem, na podstawie którego zakażenie

${ }^{1}$ Podkreśla on, że kwestia przewidywalności jest zatem ujęta odmiennie niż pod rządami art. $269 \mathrm{KZ}$, który wymagał „niemożności przewidzenia”. 
tym wirusem zostało objęte przepisami o zapobieganiu oraz zwalczaniu zakażeń i chorób zakaźnych u ludzi (§ 1). Następnie 2 marca 2020 r. uchwalono ustawę o szczególnych rozwiązaniach związanych z zapobieganiem, przeciwdziałaniem i zwalczaniem COVID-19, innych chorób zakaźnych oraz wywołanych nimi sytuacji kryzysowych (która weszła w życie 8.03.2020 r.). I choć trudno nie postrzegać tych aktów prawnych jako regulacji przełomowych, zwiastujących zmiany nadchodzące $\mathrm{w}$ związku z pojawieniem się pierwszych pacjentów zakażonych koronawirusem w Polsce, o tyle nie sposób przyjąć, że samo uchwalenie, czy nawet wejście w życie, pozwoliło stronom na przewidzenie, jakie następstwa akty te spowodują względem konkretnej, łączącej je umowy. Tym bardziej, że o ile akty prawne stanowiły fundament dla wszelkich działań podejmowanych przez państwo, o tyle dla konkretnych umów często to właśnie działania podejmowane przez władze państwowe czy polecenia formułowane w mniej oficjalny sposób np. w drodze podejmowanej akcji \#zostanwdomu, miały mieć kluczowe znaczenie. Zgodzić się przy tym należy z poglądem wyrażonym przez K. Kurosza i W. Matysiaka, zgodnie z którym na zdolność przewidywania konkretnych następstw pandemii koronawirusa wpływ w równym stopniu miały też reakcje społeczeństwa, stanowiące zarówno skutek uboczny działań władz państwowych, jak i często bodziec do podejmowania takich działań przez państwo (Kurosz, Matysiak 2020). Ze względu na wyjątkową złożoność opisywanego zjawiska, określenie jednego, tożsamego momentu, od którego strony, które związane były stosunkiem zobowiązaniowym zaciągniętym przed połową marca 2020 r., mogły przewidywać, jakie następstwa przyniesie wprowadzenie stanu pandemii na konkretne zobowiązanie, jest niemożliwe i powoduje konieczność określania tego momentu, biorąc pod uwagę zindywidualizowany kontekst, w którym doszło do zawarcia konkretnej umowy przez określone strony.

Jeszcze więcej wątpliwości rodzić będzie ocena stosunków zobowiązaniowych nawiązanych w połowie marca 2020 r., bądź też na początku kwietnia 2020 r., bowiem o ile strony, które nawiązując stosunek zobowiązaniowy przy zachowaniu odpowiedniej staranności, jakiej można wymagać od stron stosunku prawnego w różnorodnych sytuacjach wywołanych przebiegiem zdarzeń po zawarciu umowy (Olejniczak 2018, 147), nie mogły przewidzieć następstw, jakie pandemia wywoła w odniesieniu do łączącego je stosunku prawnego, powinny mieć możliwość skorzystania z klauzuli rebus sic stantibus, o tyle działania podejmowane przez strony bezmyślnie, czy w sposób nieprzemyślany, na taką ochronę nie zasługują. Co więcej - strona, która działa w taki sposób i skutki swojego nieprzewidzenia stara się przerzucić na drugą stronę, nie będzie mogła skorzystać ochrony przewidzianej w art. 357(1) k.c. (Olejniczak 2018, 149). Takie założenie eliminuje możliwość skorzystania z praw przewidzianych w klauzuli przez stronę, która przy zachowaniu należytej staranności mogła przewidzieć następstwa pandemii względem łączącego ją z inną stroną stosunku zobowiązaniowego, co z kolei znowu determinuje konieczność rozstrzygania tego typu stanów faktycznych 
w sposób zindywidualizowany, po wyjątkowo skrupulatnej analizie stanu faktycznego. Zgodzić przy tym należy się ze stanowiskiem SN, zgodnie z którym w sytuacji, w której strony zawierały umowę w anormalnych warunkach, a stan pandemii niewątpliwie takie anormalne warunki kreuje, licząc na ustabilizowanie stosunków w czasie wykonywania umowy, a do oczekiwanego ustabilizowania stosunków nigdy nie doszło, to nie można się powołać na art. 357(1) k.c. (wyr. SN z 18.05.2006 r., IV CSK 8/05, LEX Nr 200925). W konsekwencji wydaje się więc, że strony zawierając umowę już w momencie, kiedy wszystkie równolegle ww. czynniki nie tylko wystąpiły, ale też spowodowały szereg następstw, we wszystkich sferach życia, to przy zachowaniu należytej staranności powinny przewidywać, że pojawiające się w kontekście epidemii zjawiska gospodarcze i społeczne mogą mieć wpływ na ich stosunek zobowiązaniowy, a więc nie będą mogły z klauzuli z art. 357(1) k.c. skorzystać, bowiem wiemy, że do ustabilizowania anormalnych warunków jeszcze nie doszło.

\section{ZAKRES ZASTOSOWANIA KLAUZULI REBUS SIC STANTIBUS}

Nie ulega wątpliwości, bo wynika to z literalnego brzmienia przepisu, jak również jest to powszechnie przyjęty w doktrynie pogląd, że w zakresie zastosowania art. 357(1) k.c. mieszczą się umowy rodzące zobowiązania, przy czym zgodzić należy się z poglądem prezentowanym przez A. Olejniczaka, że są to wszelkie umowy rodzące zobowiązania (Olejniczak 2018, 103). Przyjmując pogląd, zgodnie z którym klauzula ma zastosowanie względem wszelkich umów rodzących zobowiązania, nie można sformułować innego wniosku niż, że pod pojęciem „wszelkie" mieszczą się wszystkie umowy niezależnie od ich charakteru prawnego, rodzaju świadczenia czy miejsca lub formy ich zawarcia. Bez znaczenia pozostaje również to, czy umowa ma charakter umowy wzajemnej, odpłatnej lub nieodpłatnej, bądź czy przedmiotem świadczenia jest świadczenie pieniężne czy niepieniężne. Każda umowa, w przypadku której spełnienie świadczenia byłoby połączone z nadmiernymi trudnościami albo groziłoby jednej ze stron rażącą stratą, wchodzi w zakres zastosowania art. 357(1) k.c. Co więcej, nie ma również znaczenia, czy strona umowy jest przedsiębiorcą, czy też nie, choć już obecnie wskazuje się w doktrynie, z czym trudno się nie zgodzić, że szczególne znaczenie w kontekście pandemii koronawirusa klauzula będzie miała dla przedsiębiorców, bowiem ich sytuacja może się znacząco poprawić na skutek rozwiązania czy modyfikacji pojedynczych umów (Strugała 2020).

Odmienne stanowisko, odnośnie zakresu zastosowania klauzuli rebus sic stantibus, zgłosili B. Nowak-Górski, D. Mróz i K. Olszak. Wskazali oni, że klauzula nie może mieć zastosowania dla umów, których przedmiotem jest świadczenie pieniężne z uwagi na fakt, że w XXI wieku gospodarka rynkowa jest wysoce rozwinięta, a systemem finansowy jest dojrzały, więc spełnienie takiego świadczenia 
nie może być uznane za nadmiernie utrudnione (Nowak-Górski, Mróz, Olszak 2020, 507). O ile nie sposób nie zgodzić się z tezą autorów, że gospodarka rynkowa jest obecnie wysoce rozwinięta, o tyle założenie, że łatwość, z jaką obecnie można dokonać czynności faktyczne, polegające wyłącznie na spełnieniu świadczenia pieniężnego z użyciem nowoczesnych technik i technologii, powoduje, że spełnienie takiego świadczenia nie może łączyć się z nadmierną trudnością dla dłużnika, jest błędne. Nadmierna trudność pojawia się wtedy, gdy spełnienie świadczenia przez dłużnika, mogłoby grozić mu niebezpieczeństwem utraty życia, uszczerbkiem zdrowia (Longchamps de Berier 1948, 417), a założenie, że łatwość, z jaką w dzisiejszych czasach można dokonywać operacji pieniężnych, implikuje samo przez się, że spełnienie takiego świadczenia pieniężnego nie może wiązać się z nadmierną trudnością po stronie dłużnika, wydaje się być spowodowane błędnym rozumieniem przesłanki nadmiernej trudności. Fakt, że sama czynność dokonania przelewu może być wykonana z łatwością, bowiem przyjąć można, że właściwie jedynym koniecznym do jej wykonania warunkiem jest posiadanie połączenia z Internetem na dowolnym urządzeniu tj. telefonie czy komputerze, nie powoduje, że zapłata określonej sumy, w szczególności dużej, nie może spowodować choćby popadnięcia w stan ubóstwa i w efekcie przyczynić się do powstania niebezpieczeństwo utraty życia przez dłużnika. Łatwość dokonania przelewu nie przekłada się przecież na łatwość zgromadzenia potrzebnych do jego wykonania środków pieniężnych na koncie bankowym, a przecież to właśnie dysponowanie środkami pieniężnymi ma znaczenie w kontekście przesłanek z art. 357(1) k.c. Co więcej, tak przyjęte rozumowanie spowodowałoby nadmierne zawężenie zastosowania klauzuli jedynie w odniesieniu do umów, których przedmiotem jest świadczenie niepieniężne. Ma to ogromne znaczenie również w związku z faktem, że obecnie wskazuje się, że jeden z największych kryzysów spowodowany pandemią koronawirusa może dotknąć rynek nieruchomości (Strugała 2020), natomiast umowy przedwstępne, deweloperskie czy umowy sprzedaży, nagminnie występujące w tej branży, a w których niewątpliwe strony na skutek pandemii koronawirusa będą dążyć do obniżenia cen, by odpowiadały cenom rynkowym, to umowy, w których przedmiotem świadczenia jednej ze stron jest właśnie świadczenie pieniężne i brak jest podstaw do tego by przyjąć, że strona takiej umowy nie może mieć nadmiernych trudności przy jej wykonaniu. Oczywiście, nie ogranicza się to wyłącznie do rynku nieruchomości, bowiem przy przyjęciu takiej tezy szereg umów bezpodstawnie zostałby wyłączony z zastosowania art. 357(1) k.c. Nie powinno więc nastąpić wykluczenie z zakresu zastosowania klauzuli rebus sic stantibus umów, których przedmiotem jest świadczenie pieniężne, bowiem, pomimo że w XXI wieku ułatwione jest dokonanie samej czynności zapłaty określonej sumy, to wykonanie takiej umowy wciąż może stanowić nadmierną trudność dla dłużnika.

W kontekście pandemii koronawirusa rodzi się jeszcze jeden problem prawny, mianowicie relacja artykułu 357(1) k.c. do regulacji zawartych w tzw. tarczy 
antykryzysowej. Nie budzi zastrzeżeń fakt, że wiele przepisów tego aktu prawnego wpływa na postanowienia zawarte w umowach nawiązanych przed wybuchem pandemii koronawirusa, modyfikując treść postanowień tych umów lub nawet zupełnie rozwiązując stosunki prawne powstałe na skutek zawarcia takiej umowy z mocy samego prawa (ex lege). Na skutek zastosowania przepisów wynikających z tzw. tarcz antykryzysowych będziemy mieć do czynienia z umowami pierwotnie w całości ukształtowanymi przez strony, które taką umowę zawierały, a następnie zmodyfikowanymi z mocy samego prawa i obowiązującymi w tym zmienionym (niezależnie od woli stron) kształcie. Nie ulega wątpliwości, że tego typu arbitralne modyfikacje umów są reakcją państwa na następstwa pandemii koronawirusa, a także próbą zachowania równowagi pomiędzy obciążeniami stron określonych umów. Zgodzić się przy tym należy z tezą R. Strugały, że rozwiązania przyjęte w tarczach antykryzysowych bez wątpienia są dużo skuteczniejsze od rozwiązania przewidzianego $\mathrm{w}$ art. 357(1) k.c. choćby z uwagi na to, że działają ex lege, bez potrzeby wytaczania powództwa o ukształtowanie. Pozwalają więc przy tym „ominąć" długotrwały proces (Strugała 2020). Jednakże postawienie tezy, że przewidziana w tarczach antykryzysowych arbitralna modyfikacja umów doprowadzi $\mathrm{w}$ istocie do wprowadzenia równowagi i sprawiedliwości w każdym stosunku umownym, do którego zastosowanie mają przepisy tego aktu, jest nad wyraz optymistyczne. Zbyt daleko idące są twierdzenia, że na skutek tego typu modyfikacji spełnienie świadczenia przez stronę nie będzie połączone z nadmierną trudnością, bądź też nie będzie groziło którejkolwiek ze stron rażącą stratą. W tej sytuacji to właśnie klauzula rebus sic stantibus jako „klapa bezpieczeństwa”, która może zostać wykorzystana w sytuacjach absolutnie wyjątkowych (Brzozowski 2020, 19) stanowić będzie rozwiązanie dla stron. Klauzula z art. 357(1) k.c. ma mieć przecież zastosowanie w sytuacjach wyjątkowych, normalnie niespotykanych (Morek 2020, 19). Wydaje się więc, że przyjęcie stanowiska, że rozwiązania przyjęte w tarczy antykryzysowej są alternatywą wobec art. 357(1) k.c., a w konsekwencji, jeżeli rozstrzygają o wpływie wybuchu pandemii COVID-19 na prawa i obowiązki stron umowy, wyłączają zastosowanie klauzuli rebus sic stantibus (Strugała 2020), wypacza sens istnienia tej klauzuli, jako że ma ona przede wszystkim zmierzać do dostosowania stosunków umownych do zmienionych okoliczności w sposób odpowiadający zasadom słuszności i powszechnemu poczuciu sprawiedliwości (Bieniak 2020, 77) względem konkretnej umowy oraz przy uwzględnieniu kontekstu indywidualnych uwarunkowań stron.

\section{ZAGADNIENIA PROCESOWE}

Nie ulega wątpliwości, że modyfikacja stosunku przy wykorzystaniu klauzuli rebus sic stantibus będzie wymagała ingerencji sądu. Nie jest możliwa zmiana bądź rozwiązanie umowy na podstawie oświadczenia woli jednej ze stron, 
chociażby w jej mniemaniu ziściły się wszystkie przesłanki przewidziane w art. 357(1) k.c. (Morek 2020, 34). Stosownie do treści art. 357(1) k.c., po rozważeniu interesów stron i zgodnie z zasadami współżycia społecznego, sąd może oznaczyć sposób wykonania zobowiązania, wysokość świadczenia lub nawet orzec o rozwiązaniu umowy. W tym ostatnim przypadku ma także możliwość orzec o rozliczeniach stron, kierując się ich interesem oraz zasadami współżycia społecznego, natomiast wyrok orzekający zmianę sposobu wykonania zobowiązania, wysokości świadczenia lub rozwiązujący umowę ma charakter konstytutywny (Stec 2020, 191).

Zgodnie z powszechnie przyjętym $\mathrm{w}$ doktrynie, jak i aprobowanym w orzecznictwie poglądem, podstawą ingerencji sądu w stosunek umowny na podstawie art. 357(1) k.c. jest powództwo o ukształtowanie stosunku prawnego, przy czym żądanie to będzie obejmowało - według wyboru powoda - określone oznaczenie przez sąd sposobu wykonania zobowiązania (np. rozłożenie świadczenia na raty, zmianę terminu jego spełnienia), zmianę wysokości świadczenia (jego obniżenie bądź podwyższenie) lub orzeczenie o rozwiązaniu umowy przez sąd. W doktrynie wskazuje się również na możliwość zastosowania klauzuli z art. 357(1) k.c. po wytoczeniu powództwa wzajemnego (wyr. SN z 22.09.2011 r., V CSK 420/10, OSNC 2012/5/61, uchw. SN z 27.03.2001 r., III CZP 54/00, OSNC 2001/10/145). Jak jednak podkreśla SN, wykazanie istnienia tych przesłanek spoczywa na powodzie, który domaga się interwencji sądu polegającej na modyfikacji treści danego stosunku zobowiązaniowego (tak np. wyr. SN z 22.06.1998 r., I CKN 755/97, Lex Nr 1219554). Pogląd ten, mimo upływu lat, wciąż pozostaje aktualny (tak m.in. wyr. SA w Szczecinie z 25.04.2013 r., I ACa 83/13, Lex Nr 1378861). Należy przy tym zwrócić uwagę, że pozew o ukształtowanie stosunku prawnego opartego na nadzwyczajnej zmianie stosunków z art. 357(1) k.c. musi zostać wniesiony przed wygaśnięciem zobowiązania (tak m.in. wyr. SN z 21.07.2006 r., III CSK 119/05, LEX Nr 445269; wyr. SN z 9.04.2003 r., I CKN 255/01, Lex Nr 78890, czy wyr. SA w Katowicach z 25.11.2010 r., V ACa 409/10, OSP 2012, Nr 5, poz. 46).

Nie ulega jednak wątpliwości, że pandemia koronawirusa oddziałuje negatywnie na wiele sfer życia, przy czym nie ogranicza się to jedynie do stosunków gospodarczych czy społecznych, ale w dużej mierze również oddziałuje na polskie sądownictwo. Szereg rozpraw i posiedzeń jawnych w polskich sądach jest odwoływanych w drodze zarządzeń wydawanych przez Prezesów sądów (tak. m.in. Zarządzenie Nr 90/2020 Prezesa Sądu Rejonowego dla Łodzi-Śródmieścia w Łodzi z 30 października 2020 r.). Odwoływanie rozpraw i posiedzeń jawnych, ograniczony dostęp do sądów osób trzecich, a w tym przecież powodów i pozwanych, braki kadrowe w sądach, kwarantanny sędziów oraz pracowników sądów powodują, że trzeba zaryzykować tezę, że postępowania sądowe, które już przed zdarzeniami związanymi z zakażeniami wirusem SARS-CoV-2 miały charakter długotrwały, często trwające kilka lat, mogą ulec kolejnym przedłużeniom, a w konsekwencji ochrona przyznawana stronom w drodze art. 357(1) k.c. 
może mieć charakter prowizoryczny, tym bardziej że klauzula ma zastosowanie jedynie w sytuacji, gdy świadczenie stanowiące przedmiot umowy nie zostało jeszcze spełnione. Wydaje się więc, iż pomimo że SN wielokrotnie wypowiadał się przeciwko możliwości obrony przy powołaniu się na zarzut wywodzony z art. 357(1) k.c. (tak m.in. uchw. SN z 27.03.2001 r., III CZP 54/00, OSNC 2001, Nr 10, poz. 145), wyr. SN z 13.01.2000 r., II CKN 644/98, MoP 2000, Nr 12, poz. 791), wskazując że ,żądanie dostosowania umowy do zmienionych okoliczności może być realizowane jedynie przez wytoczenie powództwa lub powództwa wzajemnego, nie zaś w drodze zarzutu procesowego" (wyr. z 22.06.2018 r., II CSK 539/17, OSNC - Zb. dodatkowy 2019, Nr C, poz. 37, 33), a także, że to charakter regulacji zawartej w art. 357(1) k.c., umożliwiającej domaganie się wydania orzeczenia o określonej treści, mającego postać konstytutywnego rozstrzygnięcia sądu powoduje, niemożność domagania się zastosowania go w formie zarzutu (wyr. z 21.06.2001 r., IV CKN 385/00, LEX Nr 52481), zauważyć jednak należy, że dopuszczenie formułowania zarzutu procesowego przez pozwanego na gruncie art. 357(1) k.c. byłoby pewnym rozwiązaniem niespotykanych jak dotąd, a wywołanych pandemią koronawirusa, problemów Polskich sądów. Taki pogląd nie jest zresztą żadnym novum, bowiem przedstawił go już M. Waligórski, według którego na tle art. 269 k.z. nie doznaje wyjątków zasada, zgodnie z którą pozwany może wystąpić w procesie z powództwem, jak i zgłosić zarzut (Waligórski 1947, 116). Również W. Robaczyński, wskazuje, że na gruncie art. 357(1) k.c. nie ma podstaw do tego, aby wyłączyć możliwość powołania się na nadzwyczajną zmianę stosunków w formie zarzutu zgłoszonego przez pozwanego, bowiem ustawodawca nie wprowadził w tym zakresie żadnego ograniczenia (Robaczyński 1998, 70). Przy braku literalnie wyrażonego ograniczenia nie ma też podstaw do tego, aby takie ograniczenie wprowadzić w drodze wykładni przepisu 357(1) k.c. Na dopuszczalność zgłoszenia zarzutu zmierzającego do ukształtowania przez sąd stosunku zobowiązaniowego przez oznaczenie sposobu wykonania zobowiązania lub określenie wysokości dochodzonego świadczenia w zarzutach od nakazu zapłaty wskazuje się również w judykaturze (tak np. wyr. SA w Warszawie z 12.12.2016 r., I ACa 1098/15, Legalis Nr 1564212), z uzasadnienia wyroku Sądu Apelacyjnego w Warszawie wynika, że stanowisko, że żądanie zastosowania art. 357(1) k.c. powinno nastąpić w pozwie lub pozwie wzajemnym musi być ad casu łagodzone. W przytoczonym wyroku sąd dopuszcza co prawda możliwość formułowania zarzutu na gruncie art. 357(1) k.c., ale wyłącznie wtedy, gdy zarzut zmierza do ukształtowania stosunku zobowiązaniowego przez oznaczenie sposobu wykonania zobowiązania lub określenie wysokości dochodzonego świadczenia lub gdy powództwo wzajemne jest niedopuszczalne, a żądanie pozwu dotyczy całej kwoty z danego stosunku prawnego (wyr. SA w Warszawie z 12.12.2016 r., I ACa 1098/15, Legalis Nr 1564212). Autorzy wskazujący na możliwość formułowania zarzutu na podstawie art. 357(1) k.c. jednogłośnie wskazują, że za dopuszczalnością korzystania z art. 357(1) k.c. poprzez podniesienie zarzutu zdecydowanie 
przemawia ekonomika procesowa (Ostrowski 1998, 70) i wydaje się, że właśnie ten argument, w kontekście braku normatywnych przeszkód, ma tak fundamentalne znaczenie w obliczu sytuacji, z jaką przyjdzie się sądom mierzyć w związku z przewlekłością i opieszałością postępowań, które nie mogą odbywać się terminowo ze względu na pandemię koronawirusa. Słusznie również K. Kurosz i W. Matysiak wskazują, że skutecznym sposobem na łagodzenie mankamentów klauzuli rebus sic stantibus jest skorzystanie przez powoda z konstrukcji zabezpieczenia powództwa uregulowanej w treści art. 730 i n. k.p.c., bowiem na tej podstawie może on zwrócić się do sądu o udzielenie tymczasowej ochrony na czas procesu poprzez unormowanie praw i obowiązków stron (Kurosz, Matysiak 2020).

\section{PODSUMOWANIE}

Po analizie art. 357(1) k.c. uznać należy, że co do zasady dopuszczalne będzie zastosowanie konstrukcji klauzuli rebus sic stantibus do modyfikacji zobowiązań umownych w kontekście mającej miejsce pandemii wirusa SARS-CoV-2. Instytucja ta nie jest jednak efektywnym narzędziem ochrony stron stosunku prawnego, bo choć zastosowanie konstrukcji z art. 357(1) k.c. niewątpliwie mogłoby doprowadzić do oznaczenia na nowo sposobu wykonania zobowiązania czy nawet do rozwiązania umowy, to należy zwrócić uwagę, że w kontekście problemów, $\mathrm{z}$ jakimi mierzy się obecnie polskie sądownictwo, a przede wszystkim w związku $\mathrm{z}$ dużymi ograniczeniami pracy sądów, strony w praktyce będą miały ogromne problemy z realizacją tego środka ochrony, a przecież skutki pandemii, choć w różnym stopniu, dotykają wszystkich uczestników obrotu gospodarczego. Niewątpliwie jednym z możliwych rozwiązań, pozwalających na bardziej efektywne działanie klauzuli rebus sic stantibus, byłoby dopuszczenie możliwości formułowania przez strony zarzutu procesowego na podstawie art. 357(1) k.c. w trakcie procesu. Jest to jednak pogląd odosobniony w doktrynie, prezentowany przez niewielu jej przedstawicieli, ponadto nie wpisujący się w dominującą linię orzeczniczą. Trwający stan epidemii obrazuje, że regulacja przewidziana w art. 357(1) k.c. jest nieefektywna i nie zapewnia uczestnikom obrotu wystarczającej ochrony ich interesów.

\section{BIBLIOGRAFIA}

Bieniak, Michał. 2020. Nadzwyczajna zmiana stosunków i jej wpływ na zobowiązania (klauzula rebus sic stantibus). Komentarz praktyczny z orzecznictwem. Red. Jerzy Bieluk. Warszawa: Wydawnictwo C.H. Beck

Brzozowski, Adam. 2020. Kodeks cywilny. Tom I. Komentarz do art. 1-449(10). Red. Krzysztof Pietrzykowski. Warszawa: C.H. Beck. 
Kurosz, Krzysztof. Wiktor Matysiak. 2020. „Klauzula rebus sic stantibus w czasie pandemii”. Przeglad Prawa Handlowego 6: 30-35.

Longchamps de Berier, Roman. Red. 1948. Zobowiązania. Lwów: Księgarnia Wydawnicza Gubrynowicz i Syn.

Malarewicz, Agnieszka. 2005. „Wpływ zmiany stosunków na wykonanie zobowiązań - cz. I”. Monitor Prawniczy 11: 539-545.

Morek, Rafał. 2020. Kodeks cywilny. Komentarz. Tom III A. Red. Konrad Osajda. Warszawa: C.H. Beck.

Nowak-Górski, Bartłomiej. Dominika Mróz. Krzysztof Olszak. 2020. „Stosowanie klauzuli rebus sic stantibus w dobie epidemii wirusa SARS-CoV-2". Monitor Prawniczy 10: 507-514.

Olejniczak, Adam. Red. 2018. Prawo zobowiazań - część ogólna. System Prawa Prywatnego. Tom VI. Warszawa: C.H. Beck.

Ostrowski, Lucjan. 1998. „Klauzula rebus sic stantibus w świetle procedury cywilnej”. Palestra 7-8: 70-73.

Robaczyński, Wojciech. Red. 1998. Sądowa zmiana umowy. Warszawa: Dom Wydawniczy ABC.

Stec, Mirosław. Red. 2020. Prawo umów handlowych. System prawa handlowego. Tom Va. Warszawa: C.H. Beck.

Strugała, Rafał. 2020. „Wpływ pandemii COVID-19 na wykonywanie umów w świetle art. $357^{1}$ KC". Monitor Prawniczy 11: 560-566.

Waligórski, Michał. 1947. „Odpowiedź na pytanie prawne”. Państwo i Prawo 5-6: 116.

Wiśniewski, Tadeusz. 2018. Kodeks cywilny. Komentarz. Tom 3. Zobowiazania. Część ogólna. Red. Jacek Gudowski. Warszawa: Wolters Kluwer Polska.

\section{Akty prawne}

Ustawa z 23.04.1964 r. - Kodeks cywilny - Dz.U.2020.1740 t.j. z 8.10.2020 r.

Rozporządzenie Prezydenta Rzeczypospolitej Polskiej z 27.10.1933 r. - Kodeks zobowiązań - tj. Dz.U. Nr 82, poz. 598.

\section{Orzecznictwo}

Wyrok SN z 22.06.1998 r., I CKN 755/97, Legalis.

Wyrok SN z 13.01.2000 r., II CKN 644/98, MoP 2000, Nr 12, poz. 791.

Wyrok SN z 21.06.2001 r., IV CKN 385/00, LEX Nr 52481.

Wyrok SN z 9.04.2003 r., I CKN 255/01, LEX Nr 78890.

Wyrok SN z 18.05.2006 r. IV CSK 8/05, LEX Nr 200925.

Wyrok SN z 21.07.2006 r., III CSK 119/05, LEX Nr 445269.

Wyrok SN z 16.05.2007 r., III CSK 452/06, LEX Nr 334987.

Wyrok SN z 22.09.2011 r., V CSK 420/10, OSNC 2012/5/61.

Wyrok SN z 19.11.2014 r., II CSK 191/14, LEX Nr 1628911.

Wyrok SA w Katowicach z 25.11.2010 r., V ACa 409/10, OSP 2012, Nr 5, poz. 46.

Wyrok SA w Szczecinie z 25.04.2013 r., I ACa 83/13, Legalis.

Wyrok SA w Warszawie z 12.12.2016 r., I ACa 1098/15, Legalis Nr 1564212.

Wyrok z 22.06.2018 r., II CSK 539/17, OSNC - Zb. dodatkowy 2019, Nr C, poz. 37, 33.

Uchwała SN z 27.03.2001 r., III CZP 54/00, OSNC 2001, Nr 10, poz. 145.

(C) by the author, licensee Łódź University - Łódź University Press, Łódź, Poland. This article is an open access article distributed under the terms and conditions of the Creative Commons Attribution License CC BY-NC-ND 4.0 (https://creativecommons.org/licenses/by-nc-nd/4.0/) 